\title{
Cepstral Peak Point Analyses of Patients Recovering from Supraglottic Laryngectomy
} Supraglottik Larenjektomiden İyileşen Hastaların Cepstral Pik Nokta Analizleri

\author{
(D) Ziya Saltürk, (D) Onur Üstün, (D Hüseyin Sarı, (D) Belgin Tutar, (D Tolgar Lütfi Kumral, (D Güler Berkiten, \\ (D) Yavuz Uyar
}

University of Health Sciences, İstanbul Okmeydanı Training and Research Hospital, Clinic of Otolaryngology, İstanbul, Turkey

\section{Abstract}

Objective: The aim of this study is to evaluate smoothed cepstral peak point and laryngostrobosopic results in patients who underwent supraglottic laryngectomy.

Method: Ten patients who underwent transcervical supraglottic laryngectomy with bilateral modified radical neck dissection, and who completed at least 12 months of follow-up, were included. All patients underwent laryngostroboscopic evaluation at study commencement; glottal closure and mucosal wave pattern were examined. Voice records were taken at fundamental frequency and smoothed cepstral peak point were analysed. Voice handicap index-10 was requested to be completed. Ten healthy individual constituted control group. Results were compared. Results: The mean smoothed cepstral peak points were 1.53-5.91 in the supraglottic laryngectomy group and 4.6-6.06 in controls, a significant difference. The fundamental frequency ranged from 174.49 to $197.25 \mathrm{~Hz}$ in the supraglottic laryngectomy group and from 118.57 to $197.61 \mathrm{~Hz}$ in the control group, also a significant difference. Laryngostroboscopic evaluation revealed no significant between-group differences in closure, but the mucosal waves differed significantly. Voice handicap index was significantly lower in supraglottic laryngectomy patients.

Conclusion: Supraglottic laryngectomy reduces smoothed cepstral peak point and affects the mucosal wave, reducing voice quality.

Keywords: Cepstral peak point, supraglottic laryngectomy, laryngostroboscopy, vocal quality, voice handicap index

\section{Öz}

Amaç: Bu çalışmanın amacı, supraglottik larenjektomi geçiren hastalarda kepstral pik noktası ve laringostroboskopik sonuçları incelemektir.

Yöntem: Transservikal supraglottik larenjektomi ve bilateral modifiye boyun diseksiyonu olmuş, en az 12 ay takip edilmiş 10 hasta çalışmaya dahil edildi. Bütün hastalar çalışmanın başlangıcında laringostroboskopiyle incelendi; glottik kapanış ve mukozal dalga paternleri incelendi. Temel frekanslarda ses kayıtları alındı ve kepstral pik noktası analiz edildi. Voice handicap index-10 tamamlanması istendi. On sağlıklı bireyden kontrol grubu oluşturuldu. Sonuçlar karşılaştırıldı.

Bulgular: Supraglottik larenjektomi grubunda ortalama kepstral pik noktası 1,53-5,91, kontrol grubunda ise 4,6-6,06 olarak bulundu, sonuçlar istatistiksel olarak anlamlı bulundu. Supraglottik larenjektomi grubunda temel frekans 174,49 ile $197,25 \mathrm{~Hz}$ arasında, kontrol grubunda ise 118,57 ile $197,61 \mathrm{~Hz}$ arasında değişmiştir ve sonuçlar istatistiksel olarak anlamlı bulunmuştur. Laringostroboskopik incelemede glottik kapanışta iki grup arasında anlamlı fark bulunmazken, mukozal dalgalarda anlamlı fark saptandı. Voice handicap index, supraglottik larenjektomi hastalarında anlamlı olarak daha düşük bulunmuştur.

Sonuç: Supraglottik larenjektomi, kepstral pik noktasını düşürürken, ses kalitesini düşürerek mukozal dalgaları etkiler.

Anahtar kelimeler: Kepstral pik noktası, supraglottic larenjektomi, laringostroboskopi, ses kalitesi, voice handicap index

Address for Correspondence: Ziya Saltürk, University of Health Sciences, İstanbul Okmeydanı Training and Research Hospital, Clinic of Otolaryngology, İstanbul, Turkey

E-mail: ziyasalturk@gmail.com ORCID ID: orcid.org/0000-0001-6722-7865 Received: 15.05.2019 Accepted: 12.06.2019

Cite this article as: Saltürk Z, Üstün O, Sarı H, Tutar B, Kumral TI, Berkiten G, Uyar Y. Cepstral Peak Point Analyses of Patients Recovering from Supraglottic Laryngectomy. Bagcilar Med Bull 2019;4(2):49-52

${ }^{\circ}$ Copyright 2019 by the Health Sciences University, Bagcilar Training and Research Hospital Bagcilar Medical Bulletin published by Galenos Publishing House. 


\section{Introduction}

Supraglottic laryngectomy (SL) is a surgical procedure that preserves the vocal, deglutition, and respiratory functions of the larynx $(1,2)$. The epiglottis, aryepiglottic plica, and ventricular bands are removed during standard SL; the base of the tongue, the arytenoid cartilage, and the pyriform sinus are resected during extended SL depending on the extent of tumour invasion (3). Loss of vocal function following laryngectomy has been a major concern since laryngectomy was first introduced. Intelligible speech increases quality of life and enhances return to normal activities. The supraglottic larynx plays roles in voice production and articulation and voice quality is affected by removing it (4). Moreover, resection of the tongue base or arytenoid cartilage may have additional effects on voice quality (5).

According to Hillenbrand et al., (6) cepstrum was described as a discrete Fourier transform of the logarithm power spectrum; i.e., it was a log power of a log power spectrum. When a linear regression line representing the average sound energy is drawn through the cepstrum, the distance from the cepstral peak to this line is termed the cepstral peak prominence (CPP) $(7,8)$, a measure of the extent of harmonic organisation (7). Another such measure is the smoothed CPP (sCPP; the distance between the first harmonic peak and the point of the same frequency that lies on the regression line through the smoothed cepstrum). The logic is that a more periodic voice signal exhibits a better-defined harmonic configuration (i.e., a more harmonic spectrum), and the cepstral peak is thus more prominent. Hillenbrand et al., (6) and Hillenbrand and Houde (7) showed that the CPP was reliable and valid when used to evaluate voice quality (8). The CPP integrates waveform measures with periodicity perturbations in amplitude, frequency, and/ or noise (9). Although vocal quality is of major concern to laryngectomy surgeons, only a few studies have analyzed sCPP after partial laryngectomies (10). We analyzed sCPPs following SL.

\section{Material and Methods}

This study adhered to all relevant tenets of the Declaration of Helsinki and International Review Board approval was obtained from University of Health Sciences İstanbul Okmeydanı Training and Research Hospital Ethics Committee. A consent to publish was obtained from all the participants. Ten patients who underwent transcervical SL with bilateral modified radical neck dissection between 2010 and 2017, and who completed at least 12 months of follow-up, were included. Vocal parameters do not change significantly after 12 months (11). Ten healthy individuals including one female, matched by age and sex, constituted the control group. No patients had undergone an extended procedure. One patient was female and the others were male. Four underwent radiotherapy after surgery. We excluded patients who had undergone extended procedures, who received additional treatment because of recurrence, and who had cardiopulmonary problems that might affect voice quality.

All patients underwent laryngostroboscopic evaluation at study commencement; glottal closure and mucosal wave pattern were examined. Laryngostroboscopic evaluation was performed with 70 degree rigid telescope (Karl Storz Pulsar II, Tuttingen Germany ). All voices were recorded using an AKG D5 (AKG, Vienna, Austria) dynamic microphone and a Lexicon Alpha external sound card (Lexicon by Harman, USA). The microphone was placed 5 $\mathrm{cm}$ from the lips, and after deep inspiration, patients were told to sound the vowel "a" in Turkish for as long as possible. Praat software (version 4.4.13; Boersma and Weenink, University of Amsterdam, Amsterdam, the Netherlands) was used to analyse recordings and the Z-tool (James Hillenbrand Western Michigan University) was employed for sCPP analyses.

\section{Statistical Analysis}

The results were compared using The Statistical Package for the Social Sciences (SPSS) version 22 software for Windows (SPSS Inc., Chicago, IL, USA). As subject numbers were limited, we employed the Mann-Whitney U test for comparisons.

\section{Results}

The mean age was $60.3 \pm 2.49$ years in the SL group and $57.6 \pm 4.22$ years in the control group; these did not differ significantly $(\mathrm{p}=0.209)$. The $\mathrm{sCPPs}$ were $1.53-5.91$ in the SL group and 4.6-6.06 in controls, a significant difference (Table 1) (Figure 1,2). The fundamental frequency (Fo) ranged from 174.49 to $197.25 \mathrm{~Hz}$ in the SL group and from 118.57 to 197.61 $\mathrm{Hz}$ in the control group, also a significant difference (Table 1). Laryngostroboscopic evaluation revealed no significant between-group differences in closure, but the mucosal waves differed significantly (Table 2).

\section{Discussion}

Although supraglottic physiology is poorly understood, compression of the false vocal folds and medial movements 
of the ventricular bands contribute to voice production $(4,12)$. Supraglottic pressure affects vocal fold vibration by accelerating and decelerating the air column (13). This pressure is a component of the input impedance controlling glottal flow and can profoundly affect vocal fold oscillation (14). Titze (15) found that voicing was impossible at a supraglottic pressure of zero.

The sCPP reflects the quality of the voice overall and the vocal tract itself, and can be used as a diagnostic test (16). HemanAckah et al., (8) found that an sCPP $<4$ evidenced dysphonia. We found that only one SL patient, but all controls, had sCPPs $>4$ (Figure 1 and 2). Thus, SL caused dysphonia. Although SL patients have been subjected to acoustic analyses $(5,17,18)$, neither the sCPP nor the CPP of such patients have been studied (to the best of our knowledge). Stone et al. (10) found that the sCPPs of patients who had undergone transoral laser microsurgery were generally low; sCPP does not depend

Table 1. Analysis of fundamental frequency and smoothed cepstral peak point results

\begin{tabular}{lll} 
& Fo & SCPP \\
\hline SL & $186.00 \pm 10.11$ & $2.96 \pm 1.67$ \\
Control & $136.12 \pm 23.65$ & $5.09 \pm 0.55$ \\
$\mathrm{p}$ & 0.002 & 0.003 \\
\hline $\begin{array}{l}\text { SL: Supraglottic laryngectomy, Fo: Fundamental frequency, sCPP: Smoothed } \\
\text { cesptral peak prominence }\end{array}$ & \\
\hline
\end{tabular}

Table 2. Analysis of laryngostroboscopic records

\begin{tabular}{lll} 
& Closure & Mucosal wave \\
\hline $\mathrm{SL}$ & 6 complete and 4 incomplete & $8.8 \pm 1.63$ \\
Control & 10 complete & $10 \pm 0$ \\
$\mathrm{p}$ & 0.26 & 0.00023 \\
\hline SL: Supraglottic laryngectomy &
\end{tabular}

SL: Supraglottic laryngectomy on Fo, which is difficult to measure in severely dysphonic patients (19). The Fo, which is the principal contributor to voice perception, differed significantly between SL and control patients. Although different algorithms have been used in different studies to calculate Fo, all such studies have found that Fo changes after SL $(5,17,18)$. The vocal fold is protected during SL, enabling production of voice signals that include periodic components, and thus we could record Fo values. However, Topaloglu et al. (5) found that the extended procedure changed both the Fo and perturbation parameters.

Stroboscopy is used for both diagnosis and follow-up of laryngeal cancer (20), and to evaluate phonation after SL. We assessed glottal closure and the mucosal wave because these parameters directly affect vocal quality (21). Stroboscopy revealed no significant between-group differences in glottal closure; turbulence was absent at the glottic level. However, the mucosal wave patterns were affected in four patients (two of whom had received radiotherapy). Krausert et al. (22) also found that mucosal vibration was affected in 2 of 12 patients who had undergone SL.

This is the first study which analysed stroboscopic results and sCPPs after SL. The principal limitation of our work was the small number of patients. In addition, we did not evaluate speech, as we lacked some speech records. We could not compare patients who did and did not receive radiotherapy because patient numbers were low. Further studies on larger cohorts are required.

\section{Conclusion}

SL reduces SCPP and affects the mucosal wave, reducing voice quality. Further studies on larger cohorts are required.

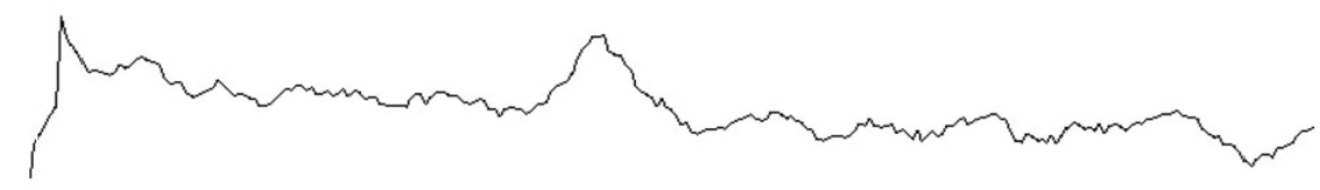

Figure 1. Smoothed cepstral analysis of supraglottic laryngectomy patients

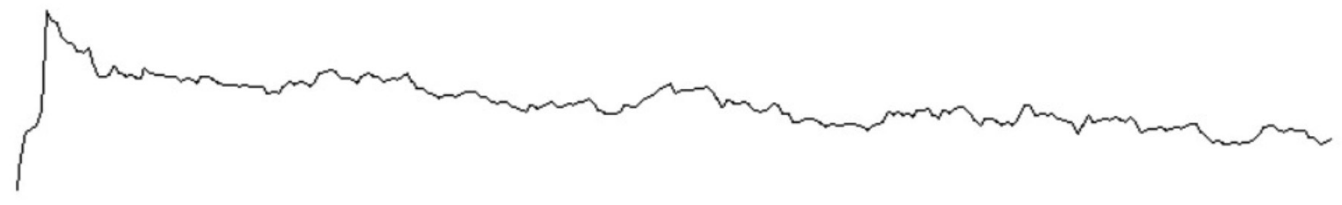

Figure 2. Smoothed cepstral analysis of healthy subject 


\section{Ethics}

Ethics Committee Approval: International Review Board approval was obtained from University of Health Sciences İstanbul Okmeydani Training and Research Hospital Ethical Comitee (date: 05.08.2018, reference number: 921).

Informed Consent: A consent to publish was obtained from all the participants.

Peer-review: Externally peer-reviewed.

\section{Authorship Contributions}

Concept: Z.S., O.Ü., H.S., Design: Z.S., O.Ü., T.L.K., Data Collection or Processing: T.L.K., H.S., B.T., Analysis or Interpretation: B.T., G.E., Y.U., Literature Search: B.T., G.B., Y.U., Writing: Z.S., O.Ü., H.S.

Conflict of Interest: No conflict of interest was declared by the authors.

Financial Disclosure: The authors declared that this study received no financial support.

\section{References}

1. M.H. Hast. Applied embryology of the larynx, In: P.W. Alberti, D.P. (Eds). Centennial Conference on Laryngeal Carcinoma. AppletonCentury-Croft, New York, 1976, pp. 6-10.

2. J.J. Pressmann, M.B. Simon, C. Monell, Anatomical studies related to dissemination of cancer of the larynx, Trans Am Acad Opthalmol Otolaryngol 1960;64:628-638.

3. Prades JM, Simon PG, Timoshenko AP, Dumollard JM, Schmitt T, Martin C. Extended and standard supraglottic laryngectomies: a review of 110 patients, Eur Arch Otorhinolaryngol 2005;262:947952.

4. Stager S. The role of the supraglottic area in voice production. Otolaryngol Cur Res 2012;2:1-7.

5. Topaloğlu I, Salturk Z, Atar Y, Berkiten G, Büyükkoç O, Çakır O. Evaluation of voice quality following supraglottic laryngectomy. Otolaryngology head and Neck Surg 2014;151:1003-1007.

6. Hillenbrand J, Cleveland RA, Erikson RL. Acoustic correlates of breathy vocal quality. J Speech Hear Res 1997;34:769-778.

7. Hillenbrand J, Houde RA. Acoustic correlates of breathy vocal quality dysphonic voices and continuous speech. J Speech Hear Res 1996;39:311-321.
8. Heman-Ackah YD, Sataloff RT, Laureyns G, Lurie D, Michael DD, et al. Heuer $r$ quantifying the cepstral peak prominence, a measure. J Voice 2014;28:783-788.

9. Flaire R, Godino-Llorente RI. Cepstral peak prominence: a comprehensive analysis. http://oa.upm.es/35802/1/INVE_ MEM_2014_190250.pdf.

10. Stone D, McCabe P, Palme CE, Heard R, Eastwood C, Riffat F et al. Voice outcomes after transoral laser microsurgery for early glottic cancer-considering signal type and smoothed cepstral peak prominence. J Voice 2015;29:370-381.

11. Makeieff M, Barbotte E, Giovanni A, Guerrier B. Acoustic and aerodynamic measurements of speech production after supracricoid partial laryngectomy. Laryngoscope 2005;115:546551.

12. Behrman A, Dahl LD, Abramson AL, Schutte HK. Anterior-posterior and medial compression of the supraglottis: signs of nonorganic dysphonia or normal postures? J Voice 2003;17:403-410.

13. Titze IR. Acoustic interpretation of resonant voice. J Voice 2001;15:519-528.

14. Titze IR, Story BH. Acoustic interactions of the voice source with the lower vocal tract. J Acoust Soc Am 1997;101:2234-2243.

15. Titze IR. A theoretica. J Voice. 2004;18:292-298.

16. Knapp RG, Miller MC, Describing the performance of a diagnostic test, In: R.G. Knapp, M.C. Miller MC (Eds) Clinical Epidemiology and Biostatistics. Harwal Publishing Company. Malvern PA, 1992, pp. 31-52.

17. Peretti G, Piazza C, Cattaneo A, De Benedetto L, Martin E, Nicolai P. Comparision of functional outcomes after endoscopic versus open-neck supraglottic laryngectomies, Ann Otol Rhinol Laryngol 2006;115:827-832.

18. Peretti G, Piazza C, Cattaneo A, De Benedetto L, Martin E, Nicolai P. Comparision of functional outcomes after endoscopic versus open-neck supraglottic laryngectomies, Ann Otol Rhinol Laryngol 2006;115:827-832.

19. Roh JL, Kim DH, Park CI. Voice swallowing and quality of life in patients after transoral laser surgery for supraglottic carcinoma. J Surg Oncol 2008;98:184-189.

20. Heman-Ackah YD, Michael DD, Goding GS Jr. The relationship between cepstral peak prominence and selected parameters of dysphonia. J Voice 2002;16:20-27.

21. Brandstorp-Boesen J, Falk RS, Boysen M, Brøndbo K. Long-term trends in gender, T-stage, subsite and treatment for laryngeal cancer at a single center. Eur Arch Otorhinolaryngol 2014;271:32333239. Doi 10.1007/s00405-014-3100-9.

22. Krausert CR, Olszewski AE, Taylor LN, McMurray CS, Dailey SH, Jiang JJ. Mucosal wave measurement and visualization techniques. J Voice 2011;25:395-405. 